平均周波数偏移を生ずる. $\Delta \omega$ が $\Delta \omega_{H}$ に近づくほよ゙， ビート波形は尖鋭なパルスになり，かつ，その繰返し周 期が大きくなるために直流分が増加し， $\Delta \omega=\Delta \omega_{H}$ にお いて， $\omega_{2}$ が $\omega_{0}$ に一致する. すなわち，フィルターがな い場合の周波数引込範囲は保持範囲に等しい.

$$
\Delta \omega_{P}=\Delta \omega_{H}
$$

（3）フィルターがあるとき

フィルターがあるときは, ビート波形の振幅が減衰す るので, $\Delta \omega_{P}$ は $\Delta \omega_{H}$ より小さくなる. 図2(a)のフィ ルターで時定数が充分大きい場合について計算すると,

$$
\frac{\Delta \omega_{P}}{\Delta \omega_{H}} \fallingdotseq 2 \sqrt{\frac{m}{3}}\left(1-\frac{m}{10}\right), \quad m=\frac{a}{b}
$$

を得る ${ }^{5)}$. 厳密な解は位相面解析で求められる

\section{8.むす ず}

テレビ系の閉ループレギュレーターは, 定位形また無 定位形の AGC, AFC, APC に分類できる.AFC とAPC は類似した機能をむつが, とくに大振幅動作における引 込現象に本質的な相違がある.
レギュレーターの縦続接続は, 分散された外乱源に対 して伝送路のダイナミックレンジの余裕を増し, また, 実効ループゲインやダイナミックレンジの配分によって 制御精度を向上できる利点があるが，総合の過渡応答に 注意して設計しなければならない.

サンプル值制御系では，一般にサンプル周期を増すほ ぞ過渡応答が振動的になる傾向があり, 線形連続解析で は不充分の場合がある. この場合, サンプル值解析によ る $z$ 平面上の根配置を $s$ 平面に写像すれば, サンプリン グの影響を同一平面内で比較することができる.

\section{〔参考 文 献〕}

1) 古橋, 熊谷: 通信と自動制御, 通信工学講座 1-B, 共立出版 (1955)

2) 三井: テレビショョパルス AFC (同期) の解析, 信学誌，44，8 (1961) 1191-1199

3） E. I. Jury（森ほか訳）：サンプル值制御，丸善 (1962)

4）竹中，山中：標準化したテレビサテライト装置 (4), 放送技術, 19, 9 (1966) 745-752

5）吉田，荻原，玉井：FM ステレオ送信機，NHK 技術研究，17, 4 (1965) 273-278

6）広田, 鍋山, 宮崎: テレビジョンの水平 AFC における同期引込 現象の解析，テレビ誌，21，8 (1967) 553-563

\title{
楅”テレビジョン放送局における近代化
}

\section{3-2 テレ シ ネ 機 器}

\section{1. まえがき}

テレシネの業務は, フィルム, スライド, テロップの 各映写装置, 光学系, これらと結合されたテレビカメラ を中心とする各種放送機器の運用操作, 調整, 保守と, 輻奏する放送素材の取扱いであり，フィルム番組のみで なく，ほとんどすべての番組と関連を有する．特に民間 放送では，コマーシャルのほとんど大部分をテレシネに 依存しており，重要な役割を有している，しかし，その 業務はかなり多岐に分かれている屯のの, カラ一カメラ の調整などごく一部を除いては，平常時においては高度 の熟練ないし判断を要するものではなく，また，操作者 の個性が要求されるものでもない.それぞれの作業は自 動送出装置からの制御あるいは単体機器の自動化に置換 されるべき性格を有しており，また，その一部は放送素

"3-2 Telecine Equipment" by Kyoichi Takeshita (Nippon Educational Television Co., Ltd., Tokyo)

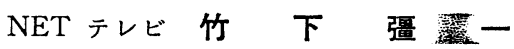

材の処理上の約束に転化さるべき宿命を有している.

テレシネの近代化の特徴は, 単体機器の自動化のみ はなく, 放送素材およびその処理の規格化と密接に関連 し, また, その機械的強度や形状, 寸法など, 素材の確 実性が必要亡される点である. これらの問題は, 素材の 制作ないし準備作業のシステム全般にからんでおり,さ らに，素材の局間交換が行なわれるために，容易には解 決できない性格をもっている.

\section{2. テレシネ業務の使用目的別分類}

テレシネの業務を対象別に分類すると, (1)放送送出 業務，（2）制作業務，（3）報道制作業務となり，テレシ ネ機器の近代化を考える場合，それぞれ異なる条件をも っている.

\section{（1）放送送出業務}

この場合の特徵は, 数多くの放蒵素材を正確な時間ス ケジュールで再生しなければならないとと, 作業が全放 
送時間にわたり断続的に分布していることである.した がって, テレシネ機器の近代化に要求される条件は, そ れ自体が多数の素材をストックできるとと, その素材群 を順次自動装填し, 放送自動送出装置加らの制御信号に より自動的に再生されること, 再生終了後は自動的にリ セットし, 回収されうることである. また, 特に機器の 動作の高度の安定性と信頼性が求められる。

\section{（2）制作業務}

スタジオ番組の制作に使用される場合は, プレビュー, リハーサル, 本番という具合に, 反覆再生される場合が 多い. したがって, 特に容易に反覆再生しうるような機 構が必要であり,リモートコントロールしうるととが望 ましい.

\section{（3）報道業務}

報道制作業務は，他の制作とまったく異なり，極端な 迅速性が要求され, 短時間のうちに編集送出業務が集中 する. したがって, テレシネ機器の近代化はこの迅速性 を犠牲にするあのであってはならないし, むしろ, 迅速 性を增大するあのでなければならない. また, ニュース 項目の変更に応じうるものでなければならない.

テレシネ機器の近代化は, 現在の段階は, まだ在来形 の単体機器の諸機能の自動化にとどまっているが，上記 三業務について合目的的に考えるならば，万能形は不可 能であって，それぞれに最む適合した装置に分化せざる を得ないあのと考えられる.

現在, テレシネ機器の配置は, 一般に放送業務を中心 とした考えで集中して配置されており，その中で，制作 業務用のチャネル, コマーシャル用のチャネルなどに分 けて運用しているのが普通である。しかし，NHK 東京 では, テロップ装置は各副調整室付属として分散配置 し, 制作用フィルムプロジェクタ一室を完備し, 報道業 務はニュースセンターで編集制作業務と一体化して処理 している. 集中配置は, 近代化されないテレシネにおい て, 熟練者の有効な配置という极らいでとらえられた措 置であるが，設備の基本方針であるために，近代化の前 に横たわる大きな問題となろう.

\section{3. 単体機器の自動化}

\section{1 フィルムプロジェクター}

自動化の状態を表 1 に示す. 表に示された自動化項目 の他に, パーフォレーションの破損によって生ずるフィ ルムの掻き落しミスを修正し，フィルム流れを防止する 自動ループセッター,フィルム終了時の映写自動停止機 構などが害用化されている，自動化各項目は，いずれも 高度の確実性が必要であり，現在行なわれているような 時間クッションをむたない番組送出形式では，わずかな
誤動作も大きな放送事故に直結する.

(1) 自動装填

8 ミリ映写機で行なわれているのと同様なフィルムガ イド方式が試作されてはいるが1. 実用化されていない. との方式の欠点は, 動作不確実な場合に手動装填に切換 えるのが困難であり, また, フィルム切断や掻き落し不 良, 音声トラブルなどに対し適切な措置がとり難いとい う点である. したがって, 動作の確実性の他に, 素材が このような方式に充分対応できるあのであるととが要求 される.すなわち，

（a）フィルムベースの充分な強度

（b）フィルム寸法精度, 特にパーフォレーション 精度の向上

(c) フィルムベースの経年変化, 特にシュリンケ 一ジの解消

（d）フィルム編集の改善, 編集部分の強度の向上, 精度の向上, 経年変化の解消, 熟練度を含む個人差を 解消する編集方法の改善

（e）フィルム検査機の開発，特にフィルム不良部 分の自動検出ないし自動補修の機能を有すること が満足されなければならない。このような素材の確実性 の向上は, プロジェクターの近代化に当って, きわめて 重要である.

フィルムの輸動方式は, 一般に間欠方式が用いられて いるが, 自動装填のためには連続方式のほうが技術的に 容易であろう. 間欠方式では, 映写部が間欠輸動であり 音声再生部が連続輸動であるために，スプロケット，テ ンションアーム, フライホイールからなる複雑なフィル ム経路がとられており, 自動装填が困難なばかりではな く, フィルム切断などの可能性もより大きい.

（2）頭出し（自動停止）

一般に頭出しの部分の音声トラック位置に導電箔を貼 布する方式が用いられており, 別に一部特殊リーダーの 規則的な光量変化を検出して, 規定位置に停止させる方 式”も用いられている. いずれも充分な確実性を有して おり，技術的な問題は解決されている.

ただ残されている問題は, 導電䇴検出方式では, 導電 箔貼布位置の統一, フィルム頭出し位置の統一(フィル ムプロジェクタ一の立上り特性の統一), 貼布の自動化, 導電箔の自動除去である. むちろん, 導電箔の貼布位置 の統一ができるならば, 局間フィルム交換の場合も導電 箔を貼布しなおす必要はないが，現状ではプロジェクタ 一によって貼布位置が異なり, 局によって,プロジェクタ 一の立上り特性の差から, 頭出し位置が異なっている. 統一が望ましい，導電箔の貼布の自動化は，あらかじめ リーダーロールに一定のコマ数間隔で貼布するあのとす 
表 1 単体機器の近代化の現状

\begin{tabular}{|c|c|c|c|c|c|c|c|c|c|c|c|c|c|}
\hline & 7 & $1 儿$ & ） ム & テ & 口 & プ & x & & ド & & 力 & $x$ & ラ \\
\hline & 操 作 & $\begin{array}{l}\text { 䚁の } \\
\text { 程 } \\
\text { 化度 }\end{array}$ & 方 式 & 操 作 & 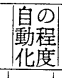 & 方 式 & 操 作 & \begin{tabular}{|c|} 
畽の程 \\
化度
\end{tabular} & 方 & 式 & 操 & $\begin{array}{l}\text { 睡の } \\
\text { 程度 }\end{array}$ & 式 \\
\hline $\begin{array}{l}\text { 被 } \\
\text { 制 } \\
\text { 御 } \\
\text { 機 }\end{array}$ & 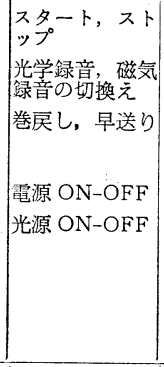 & $\left|\begin{array}{l}0 \\
0 \\
\Delta \\
0 \\
0\end{array}\right|$ & 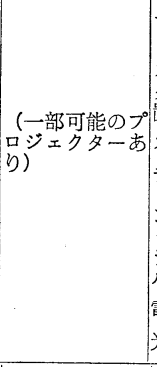 & 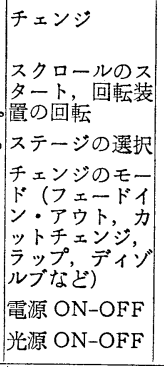 & $\left|\begin{array}{l}0 \\
0 \\
0 \\
0 \\
0 \\
0\end{array}\right|$ & $\begin{array}{l}\text { (1)機棫式 } \\
\text { (2)真空吸着式 } \\
\\
\\
\text { (1)映像切換え } \\
\text { (2)光量調䬣 }\end{array}$ & \begin{tabular}{|l|} 
チェンジ \\
電源 ON-OFF \\
光源 ON-OFF
\end{tabular} & $\left|\begin{array}{l}0 \\
0 \\
0\end{array}\right|$ & 機械式 & & \begin{tabular}{|l|} 
衤ガーの切換え \\
ガンマ切換え \\
スーパー一, そり \\
きりの切換え \\
カララ・白黒の \\
切換え \\
色バランス補正 \\
電源 ON-OFF
\end{tabular} & $\left|\begin{array}{c}0 \\
0 \\
0 \\
0 \\
x \\
0\end{array}\right|$ & \\
\hline $\begin{array}{l}\text { 自 } \\
\text { 動 } \\
\text { 制 }\end{array}$ & 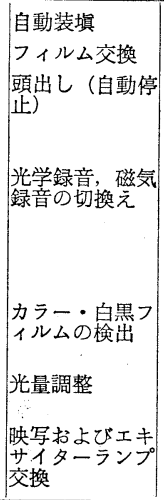 & $\begin{array}{c}\times \\
\times \\
0 \\
\times\end{array}$ & 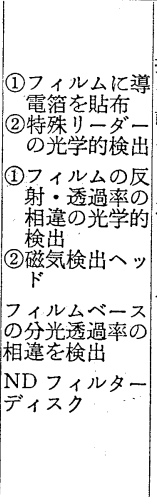 & $\begin{array}{l}\text { テロップ補充な } \\
\text { いしマガン } \\
\text { 換 } \\
\text { アクセサリー装 } \\
\text { 置の交換 } \\
\text { チェンジのモー } \\
\text { ド } \\
\text { スーパーテロッ } \\
\text { プの検出 } \\
\text { ステージの選択 }\end{array}$ & $\mid \begin{array}{l}x \\
x \\
0 \\
0\end{array}$ & 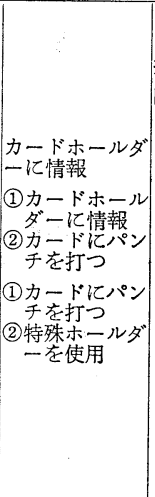 & $\begin{array}{l}\text { スライド補充な } \\
\text { 仙マガジン交 } \\
\text { 換 } \\
\text { 映写ランプ交換 }\end{array}$ & 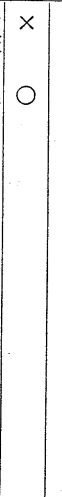 & & & \begin{tabular}{|l|} 
レベル調整 \\
\\
白レベル調整 \\
黒レベル固定 \\
ガンマ補正 \\
レジストレーシ \\
$\Xi シ$ \\
色バランス補正
\end{tabular} & $\begin{array}{c}0 \\
\\
0 \\
0 \\
0 \\
\times \\
x \\
\times\end{array}$ & $\begin{array}{l}\text { (1)壃幅度調整 } \\
\text { (2) 感度調整 } \\
\text { (ASC) } \\
\text { 白ピーク検出 } \\
\text { 黑ピーク検出 }\end{array}$ \\
\hline
\end{tabular}

（注） ○：実用化され一般化されている. $\Delta$ ：実用化されているが，不満足，あるいは一般化していない， $\times$ ：実用化されていない.

れば，比較的容易に解決できよう.

（3）光学・磁気音声ヘッド自動切換え

光学録音帯亡磁気録音帯の光の反射率および透過率の 相違を検出する方法 ${ }^{3}$ や， 録音トラックに近接して磁気 の検出ヘッドを設け，磁気録音帯によってヘッドのコア の磁気抵抗の変化を検出する方法 ${ }^{4)}$ などが試みられてい るが，まだ実用化されていない，前者は，生フィルム之 黒色フィルムの磁気録音帯の光学的相違が問題となり, 特に，磁気録音帯に半透明な光学的性質のものが開発さ れて抢り，完全な方式とはいい難い，後者は，検出感度 に問題があり，感度をあげるために検出へッドのギャッ プを狭くすれば，光学録音帯を傷つける可能性を生ず る. 今後は, より高感度高信頼度の検出ヘッドを使用し たものが考えられよう.

光学録音再生はエキサイターランプの自動交換により 安定性は增大したが，磁気録音再生は，ヘッド寿命が著 しく短く、ヘッドづまりによる再生障害屯解決されてい ない。早急な解決が必要である。

（4）カラ一・白黒フィルムの自動検出

カラー番組の中で白黒フィルムが用いられる場合, 副 搬送波バースト信号を除去するととが望ましい. 自動送
出装置により制御することも可能であるが，特にコマー シャルフィルムでは，カラー・白黒フィルムが不規則に 接続されるから，自動的に確実に識別しうればより簡略 である. このためには，カラーフィルムと白黒フィルム のベースの分光透過特性の相違が利用されている.

（5）自動光量調整 (ALC)

フィルムの濃度がカットごとに著しく変動する場合は 映写光源量を調整するととにより，テレビカメラの入射 光量を一定化するととが原則的には望ましい，一般的に は，連続的に濃度值の変化する ND フィルターディス クを光路上に挿入し，フィルムの平均透過光量に応じて この ND フィルターを回転することにより, 映写光量の 一定化を行なっている. 乙の場合, 映写機の構造上 ND フィルターがフィルムに近接して配置されていると, フ ィルター上のゴミが結像するおそれがあり，フィルター 面の清掃む困難な場合が多く，比較的に質量も大で時定 数あ大きくなる，といった欠点があり，必ずしも満足な 方法とはいい難い. 一般に光学装置では, 光量調整はレ ンズ絞りによって行なわれるが，一般の映写装置では可 変のレンズ絞りが用いられなかったために，レンズ絞り による ALC は用いられていない. 


\section{3. 被制御系一テレシネ機器}

一方, フィルムの撮影からテレビ再生に至る全過程に おけるレベル制御には，撮影 $\mathrm{EE}$ 機構 (露光調整), 自 動検度, 映写機 ALC, ビジコンカメラの AGC, ASC があり, 重複している.それぞれの自動調整に特色があ り，これらを一概にむだな重複として整理することはで きないが，回転ディスク形のNDフィルターに関しては 現在放送されているフィルムの濃度変動が比較的少ない こと，光量のロスを前提とした調整であること，画質を 劣化させる要素があるとと, 応答速度が遅すぎること, 保守が面倒なとと，などの理由から，あえて装着する必 要はないと思われる.

(6) 巻戻し (rewind)

フィルムプロジェクターをテープレコーダーの機能と 比較する場合, 著しい相違のひとつは, 早送り, 巻戻し の機能の欠除である.このことは, 別に巻き戻し機を置 くなど,フィルム作業をたいへん不便なむのとしており 特牦制作業務に扔ける反覆再生には不向きである。早送 りは特殊な場合を除いて必要ではなく, 機能としては巻 戻しが重要である. 巻戻しには 2 通りの要求が考えられ （a）映写終了後，完全に巻戻す場合，（ｂ）反覆再生の場 合で，巻戻して再び頭出しを行なう場合，である.

（a）の場合は巻戻し速度が要求され，標準映写速度の 20倍程度が必要と考えられる。( b ) の場合は，速度より あ巻戻し時の頭出しが問題となり,リモート操作で自動 的に頭出しできることが望ましく, 標準映写速度の 5 10倍が一応の基準となろう.

早送り，巻戻し可能のプロジェクターは実用化されて おり ${ }^{5)}$ ， その速度は約 6 倍であって，制作業務用として は一応充分であるが，映写終了後の巻戻しとしては不足 である.高速の巻戻しには, フィルムの重量む考えてテ ープレコーダーのようなデッキタイイプが適当であろう. ただし，このタイプでは，マルチプレクサーで他のプロ ジェクターと組合せることはできない欠点がある。

(7) その他

映写ランプの寿命は，自動交換機構により実質的に延 長されているが， $25 \mathrm{~h}$ 程度では他の部品にくらべて著し く短寿命であり, 大幅な延長が必要である. また, 球に よる色温度のばらつきや，その経時変化の除去が必要で ある. この点については，八ロゲン電球が期待されてい る.また，非常にむずかしい問題であろうが，映写中， アパーチャー部に付着したケバ状のゴミの除去む, テレ シネ近代化においては解決したい問題である.ゴミのつ きにくいアパーチャ一構造，あるいはその原因にさかの ぼって, フィルムの帯電性の減少，あるいはフィルムの 自動式高速清浄装置の開発も望ましい。

\section{2 スライドプロジェクター}

第 23 巻 第 4 号 $(1969)$
スライドプロジェクターはテロップのような効果用ア クセサリーがなく，チェンジのモードあカットチェンジ のみであり，テレビ放送の当初からオートスライドプロ ジェクターが用いられた。当初はテレシネ用独自の形式 のオートプロジエクターが用いられたが，装填容量の増 大化につれて, 現在では一般用のオートプロジェクター と同種のスライド送り機構が用いられている.

スライドは咉写順に 1 つのマガジンに配列され, 送り 爪によって順次左右のアパーチャーに送りこまれる形式 が代表的である. この種のプロジェクターの誤動作は， そのほとんどがスライドマウントの不良によって生じて いる. 一般に用いられているマウントは厚さの薄いあの が多く，放送用には不適当で，プロジェクーによっては 事故の原因となる，その他，マウントの糊の渗出し，変 形，はがれがマウント不良として考えられる。“はがれ” 以外のマウント不良によって事故が発生しないような正 確な送り機構が最も望ましい.

現用の自動スライドプロジェクターは，一般に大容量 マガジンの順次映写式であり, 放送送出業務用に適して いるが，制作業務用としては，リモート操作で反覆再生 可能なものが望ましい，乙のためには，映写後，スライ ドがマガジンのもとの位置に回収されるととと，マガジ ンの逆方向送りや，あるいはスライドのランダムセレク トができればよい。

一般用であるが，コダック社の R-100 形プロジェク ターはての要求を満足している. 円形ドーナッツ形のマ ガジンに放射状にスライドを収容し，てのマガジンより アパーチャーに取り出されて映写され, 再びマガジン内 の屯との位置に回収され, 逆方向胦写と, リモート操作 による反覆映写が可能であって, マウント不良による誤 動作も少ない. 同種の機構で, さらに連続映写可能の機 能をもったプロジェクターとして，TP-77 が $\mathrm{RCA}^{6)}$ か

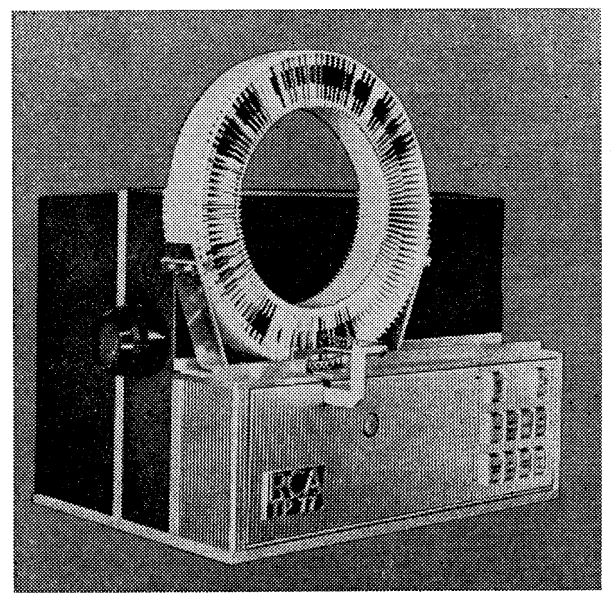

写真 1 連綕胦写可能のプロジェクター (RCA)

(41) 281 
ら発表されている(写真 1). この方式のプロジェクター は放送送出用として屯有用である。放送素材準備段階の 試写用プロジェクターに同一機構の自動プロジェクター を使用すれば，素材準備一試写一テレシネ搬入一放送一 素材回収を，一貫して同じマガジンで処理するととがで き，業務の流机は著しく合理化されるであろう。

\section{3 テロップ装置}

テロップは番組のタイトルやキャスティングなどを初 めとして，民間放送ではコマーシャルにも多用され，東 京キイ局での取扱数は，1 日当り 500 1000 枚に及んで いる．したがって，放送の当初から何らかの自動化が要 望され，現在ではほとんぞ自動テロップ装置が使用され ている。しかし，テロップ装置には，回転テロップ，ロ ールテロップなどの効果用アクセサリ一装置が多く，お のおの日に 20〜30 回程度（東京キ1局）使用されてい る現状である，てれらの装置に対しては，装置のスター トなどをりモートコントロールしうるだけであって，装 置の装填や交換などは手動操作にゆだねられている.

自動テロップの方式は，機械式 ${ }^{7)}$ 之真空吸着式 ${ }^{8)}$ の 2 種に大別するととができる，機械式は，テロップを 1 枚 1 枚特定のホールダーに装填して配列し，スライドプロ ジェクターと同種の送り装置でアパーチャーに送りとむ 方式であって, 放送準備に手間がかかるが, アパーチャー におけるテロップ位置の正確さですぐれている，真空吸 着式は，テロップをそのまま放送順に重ねて特定のケー スに収容し，吸盤で順次吸引するもので, 放送準備の面で は理想的であるが, テロップのアパーチャーに扔ける位 置が若干不正確であるとと，テロップの反りによって吸 着不良を起としやすい欠点がある．特に写真テロップは 乾燥状況によって反りやすく, テロップ装置内の熱によ って反りを生ずることも考えられ，ての方式の最大の欠 点となっている，なお，いずれの方式も，制作業務にお ける反覆再生には，再度手動による装填が必要である。

効果用テロップが多用される以上, テロップ装置の完 全な近代化は困難である。一方, 効果用テロップは, 素 材制作が非常に簡単であるから，今後とあ多用されるで あろう，その自動化のためには，従来之はまったく異な る考元方が必要であ万う．たとえば効果用専門のテロッ プ装置とし，自動化をはかることも一方法であろう。

スーパーテロップと，とりきりテロップの検出む，テ ロップ装置で行なわれている．特別なホールダーを使用 する方法，ホールダーに情報を付加する方法"，，あるい はテロップカード自体にパンチを打つなどの方法でスー パーの情報を与え，てれを検出する方法が一般にとられ ている.

非常に困難なととであるが，テロップカードの寸法自
体にも問題があろう. カラー化に伴い，特に二ュース面 に执いて，テロップ素材としてポラロイドカメラの利用 が考えられる．ポラロイド写真の大きさは，一般の写真 の手札サイズであり，テロップカードよりひとまわり小 さい，素材制作面の合理化を考える場合に，テロップカ 一ドの大きさは手札サイズをとるべきではないかと思わ れる。

\section{4 カメラ装置}

フィルムの素材間の濃度域のばらつきによる映像レベ ルの変化を自動調整するために AGC, ASC が用いられ ている. 使用の初期においては, 動作の時定数や SN 比 の劣化などに問題があったが，後に種々改善が施され また, フィルム制作過程の諸技術の向上から, 濃度のば らつきも減少し, 白黒フィルムではほぼ無調整化が達成 されている，ただ，ニュースロールにおけるネガ送出に おいて，ネガ〜ノルマルのリモート操作，ガンマ切換え とレベル調整に若干の問題が残されている.

カラーカメラにおいては，一般に NAM 検出回路が 用いられ(1), 白レベル, 黒レベルの調整を含めて AGC, ASC が行なわれている. しかし，カラーカメラの全無 調整化はまだ多くの問題を残している.カラーフィルム の制作過程における技術之管理は，まだ充分に確立され ておらず，したがって，良好なカラー画質で放送するた めには, 若干の hue のコントロールが必要である.

長尺のテレビ映画または劇場用胦画，あるいはドキュ メント映画については, 試写により事前に適切な補正量 を定め，放送に当っては補正を行なっているのが現状で ある．短尺の $\mathrm{CM}$ フィルムを放送順に編集した $\mathrm{CM}$ 口 一ルに関しては，たとえ各フィルムについて補正量がわ かっていてあ, 実際上補正は不可能であり，色調の不良 は誇張されてテレビ受信機上に再現されている.

とのような色調のばらつきは，フィルム制作抢よび処 理技術の標準化と進歩によって縮小されるであろうが, 完全に解消されるとは考えられない，乙の補正を行なう べきか否かは，色調の自動判定がきわめて困難なところ から，議論の存するところであろうが，行なうとすれば， 試写または適切なカラーアナライザーによって事前に補 正量を求め，乙れを情報化してカラーカメラに与える何 らかの方法がとられなければならない，なお，露光やフ ィルム処理に万全を期し難い二ュースロールを対象とし て，画面中のハイライトピークおよびシャドウピークを 検出し，自動的に色バランスを補正する方式が発表され ている12).

以上は，素材再生に対応するものであるが，カラーカ メラに抢いては, カメラの標準状態の調整維持にも多く の時間が費されている，特にレジストレーション，ガン 
マトラッキングの安定度は充分といえず，高安定化が必 要である. カメラの調整と傡立して, カラーモニターの 調整も重要な比率を占め, 標準調整における個人差の極 小化, 高安定化が切望されている.

\section{4. テレシネシステムの近代化}

以上は, テレシネの各単体機器の自動化について, 主 として在来形の機器を中心に述べたが, 各単体機器の自 動化につれて, 同じフィルムプロジェクターでも, 使用 目的により, 要求される自動化機能が著しく異なること が明らかとなってきた. テレシネの使用目的が, 放送送 出, 番組制作, 報道制作に大別できることはすでに述べ たが，それぞれの目的に適合した形のフィルムプロジェ クターやテロッププロジェクターが今後の課題になるも のと思われる.

放送送出テレシネの特徵は, 大量の素材の機器への供 給, 装填, および回収にある.フィルムの場合, 1 日の 放送量は, 番組本篇ロール約 20 , 番組内コマーシャル ロール約 40, ステーションブレークロール 3(朝, 昼, 夜に分けて1ロール化）が, 民間放送の東京局の場合の おおよその数字である. したがって, 送出テレシネのフ イルムプロジェクターは, 自動装填のみではあまり意味 がなく, 多装式自動装填自動回収形でなければならな W.

多装式としては, 従来のフィルムの取扱いのままに行 なわれる場合と，8ミリフィルムで行なわれているよう なカートリッジ式を応用する場合の 2 通りの方法が考え られる．後者は魅力的な方法であるが，まだ解決しなけ ればなら多くの問題があろう. 前者について考えると 映写終了後早巻戻しから次のロールの自動装填に要する フィルム切換時間は, 最大映写可能リール $60 \mathrm{~min}$, 早巻 戻しの速度は 20 倍として，4 5 min と考えられる. し たがって間に入るコマーシャル時間を考慮に入れても, 連続番組の再生は困難であり, 本篇フィルム消化のため に2 台は必要である。すなわち，本篇ロール用としては 多装式プロジェクターのフィルム収容本数は最大約 15 ロールでよいということになろう．非常に大がかりな装 置になろうが， 6 ミリテープの多装式再生機 ${ }^{13}$ は，乙の ような多装式プロジェクターの下敷きとして検討するて とが可能である.

なお，テレビ用ではないが，36リール収容の Telescopitone というプロジェクターが発表されている. 収容可 能のリールは $4 \mathrm{~min}$ までであり, 機構の詳細は不明であ るが, コマーシャルロール用の多装式プロジェクターと して参考になろう.フィルム輸動方式が連続式である点 もたいへん興味のあるととろである.
放送送出用のテロップ装置としては, 日に 650 700 枚のカードテロップを処理する必要がある. 現在の自動 テロップは，いずれも 100 枚程度の収容が可能である が, テロップの追加補充あるいはマガジンの交換の自動 化は行なわれていない. 素材の準備, 回収が番組単位で 行なわ机るととを考えると, テロップの供給, 交換, 回 収に一定の秩序が成立する方式が望ましい. との見地か らすると，NHK がニュースセンター用に開発したテロ ップ装置 (本号 74 頁参照) は, 放送送出用としても有 用ではないかと考えられる。なお，回転・ロールテロッ プのような効果用アクセサリーに関しては, 別に専用機 を設けて素材の自動供給方式を考えるべきであろう.

てのような装置の完成は, カラーカメラの高安定化に よる無調整化と相まって, ほぼ放送送出テレシネの無人 化を達成するととができる，乙かし，乙れらの諸装置は 従来の自動化単体機器に比し, はるかに高い信頼性が要 求されるから, 開発, 実用化に長い時日が必要なととを 覚悟せねばならない。

\section{VTR を用いたテレシネ送出の近代化}

ラジオ放送における送出業務がほとんどテープ化した ように，容易にテレシネ送出がビデオテープ化するすの とは考えられない.テレシネ送出の自動化が不完全な現 状において, 早朝ないし梁夜の番組送出の簡略化のため に, 完全パッケージの形でビデオテープに収録する方法 が用いられているが，ての方法が全日的に拡大されるた めには, 局の設備の大幅な増強ないし改造が必要となる からである.

しかしての方式は，テレシネの近代化というよりむし ろ民間放送局におけるステーションブレーク（SB）のコ マーシャルフィルムの編集作業の近代化として興味ある 方式と思われる.

現在, 1 日の SB 数は 50〜 60, 使用されるフィルム 素材数は約 200〜300 である. 素材はスポンサーないし 代理店より原則として 1 週間の放送本数分が持込まれ， スポンサー別に保管されているＶVTR による自動編集 は, 音声テープにおける自動編集装置とまったく同様な 考え方で, 持込まれた SB 用素材を再生してビデオテー プにファイルし，編集に当っては，1 日分の SB のタイ ムテーブルからファイルのアドレス表を作成して記憶装 置に与え, ビデオテープより順次呼出して再生する之同 時に，放送用ビデオテープ上に電子編集により連続記録 する方式である.

この方式によれば，(a)持ち込みの素材数は放送回数 にかかわらず 1 ～2本でよく，（b 最良の画質, 音質で ファイル可能であり， ( $)$ フィルム編集でさけるととの 
できない音切れないし音ずれをさけることができ，(d) 編集，分解の作業を近代化することができる.

しかし，このためには，VTR のいっそうの高安定化 が必要であり, また，ファイル容量を確保するために， ファイル用 VTR は高密度録画の開発によって 7.5 in 速度で充分な画質が得られる必要があろう. いずれにせ よ, この方式は, 少なくともファイル用 2 台, 自動編集 用 1 台, 放送用 1 台, 計 4 台の VTR が必要であり, 高 価な点が難点である.

\section{6. む び}

現在行なわれている単体機器の自動化では, テレシネ で毎日繰返される定形的な業務を完全に解消し得ないこ とは明らかである，そのためには漸新なテレシネ装置の 開発が必要であり，大幅な設備の変更，更新が必要であ って，決して短日月でなしうるものでないてとも明白で ある.

\section{〔参考 文 献〕}

1）フィルム自動装てんテレビ映写機，NHK 技術研究所研究紹介資 料 (1964.5)

2）佐藤：16 ミリ映写機自動停止頭出し装置，NAB 技術月報， 8 (1963)

3）大川: 光学フィルタを使用したコンマグフィルムの検出方法, 放 送技術，21，1 (1968) 67

4）鈴木：フィルム磁気録音带の自動検出装置，放送技術，21，1 (1968) 71

5）草萑ほか: $16 \mathrm{~m} / \mathrm{m}$ フィルムプロジェクターの瞬時起動拉よび停 止映写について, 第 1 回テレビ学会全大予, 5-8

6) RCA TP-77 カタログ B. 3050

7）石井：一連装てん式オペーク送像装置，放送技術，17，5 (1964) 298

8）小沢ほか：テロップ装置の自動化，放送技術，12，12 (1959) 677

9）森本ほ 22 回 NHK 全国技術報告会予稿（1968）

10) R.R. Brook: Impoving Automatic Sensitivity Performance in Color TV Film Camera, SMPTE, 76, 8 (1967) 792

11) 板垣ほか：RCA TK 27 カラーフィルムカメラ，放送技術，20, 7 (1967) 79

12）浜崎ほか: カラーフィルム送像の色バランス自動補正方式, NHK 技研月報, 11，11 (1968) 516

13）山陽放送新放送会館における自動化，その 1 ，放送技術，15，9 (1962) 35

14）田中：自動スポット編集装置，放送技術，17，12 (1964) 56

特 集 テレビジョン放送局における近代化

\section{3-3 VTR の 自 動 化}

\section{1. まえがき}

VTR が今日，放送番組制作打よび送出業務の重要な 一環をになっているととは論を待たないが，最近に至っ て，乙机を放送自動化システムの中組み入れて使用す る例が多くなった。

VTR はその構造, 動作が純電子的なものではなく， テープ走行系，回転ヘッドなどの機構部を有するため， ビデオテープの着脱，起動時間，並列運転の精度など， 自動化を阻害する要因も多い.

しかしながら，VTR ではこれら機構系と電気系とが きわめて有機的に結合し，起動から定常運転に入るまで に必要なプロセスがすべて自動的に行なわれ，また，運 転中あ各種の自動補償回路が㗢いて，正常動作を維持す るよう設計されているので，自動化システムと結合する ことは割合に容易である。

"3-3 Automation of VTR Operation" by Kohki Nonokuchi (Shiba Electric Co., Ltd., Hachiöji, Tokyo)

\section{芝電気株式会社 野 々 口 綱 紀}

本稿では，これらの点をVTR の構成要素と関連づけ つつ考察を行ない，あわせて将来伐された問題点など を検討してみたい，なお，番組制作におけるVTR 自動 編集については, 別稿「4-1 番組編集の近代化」でと り上げられているので，本稿では省略することとする.

\section{VTR の構成要素と自動化}

\section{1 機構系 $^{1)}$}

VTR は音声用のテープレコーダーと異なり, 回転へ ッド，真空吸引などのテープ走行系の複雑さのために， テープの着脱が困難で, カートリッジ化による自動化を 望むにはほど遠い。また,テープ走行系のテープリール， キャプスタン，回転ヘッドなどの機械的慣性は，VTR の瞬間起動㧍よび停止を妨げ, これらの負荷変動はVTR の時間軸安定度を劣化させる要素となっている.

しかし，14 in リールで $7.5 \mathrm{in} / \mathrm{sec}$ のテープ速度を使 用すれば，約 $3 \mathrm{~h}$ の録画再生が可能となり，カートリッ ジ化できない欠点をある程度カバーするし, 起動時間の 